\title{
Trends in the energy development of the Russian Federation and its Asian regions in the first half of the 21st century in the context of Russia's energy ties with the countries of northeast Asia
}

\author{
Boris Saneev ${ }^{1}$, Anatoly Lagerev ${ }^{1 *}$ and Valentina Khanaeva ${ }^{1}$ \\ ${ }^{1}$ Melentiev Energy Systems Institute of Siberian Branch of Russian Academy of Sciences, Irkutsk, Russia
}

\begin{abstract}
The present paper deals with the role of the Asian regions of Russia (Siberia and the Russian Far East) in the production and consumption of energy resources in the country for the period up to 2050 . The focus is on the dynamics and structure of energy resources outflows from the Asian regions of the country to the European part of the country and for exports to European and Asian destinations.
\end{abstract}

Keywords: energy sector, Asian regions of Russia, Northeast Asian (NEA) countries, energy resources, projection, scenarios, production, consumption, exports, prices

\section{Introduction}

The Asian regions of Russia (Siberia and the Russian Far East) have unique reserves of energy resources of allRussian and international importance.

Currently, more than $80 \%$ of Russia's energy resources are produced in its Asian regions, including $71 \%$ of the country's oil, $97 \%$ of natural gas, more than $95 \%$ of coal; more than $30 \%$ of the country's electricity is produced there as well.

In recent years, a lot of work has been done in Russia to create a list of policy documents that define the strategic development of the energy industry in the East of the country so as to take into account mutually beneficial energy cooperation between Russia and the NEA countries in the energy sector [1-4].

The Melentiev Energy Systems Institute SB RAS, also makes a certain contribution to shaping the Eastern Energy Policy, see, for example, [5].

In the materials of the program documents, much attention is paid to the Asian regions, the development of which can give an additional impetus to the development of the energy sector of the country. The Energy Strategy notes that a more dynamic growth of consumption and production of energy resources is expected in these regions, given that they are associated with the main prospects for increasing Russian energy supplies to the countries of Northeast Asia.

The development of the energy sector of Russia and its Asian regions in the long term will depend on a number of factors, among which it is important to be aware of the changes in the projection of economic development and energy consumption levels in the country and its Asian regions; in the development of the resource and raw material base of the energy sector; in the pace of scientific and technological advances in the energy sector; in the dynamics of fuel and energy prices in domestic markets of Russia; in the international energy markets situation.

\section{Modelling tools}

To estimate the effect of prospective factors on the development of the energy sector of the Asian regions we employed the basic scheme of hierarchical modelling developed at the Melentiev Energy Systems Institute, SB RAS [6], at the core of which is the dynamic model of optimization of the territorial and production structure of the country's energy sector (Figure 1), [7].

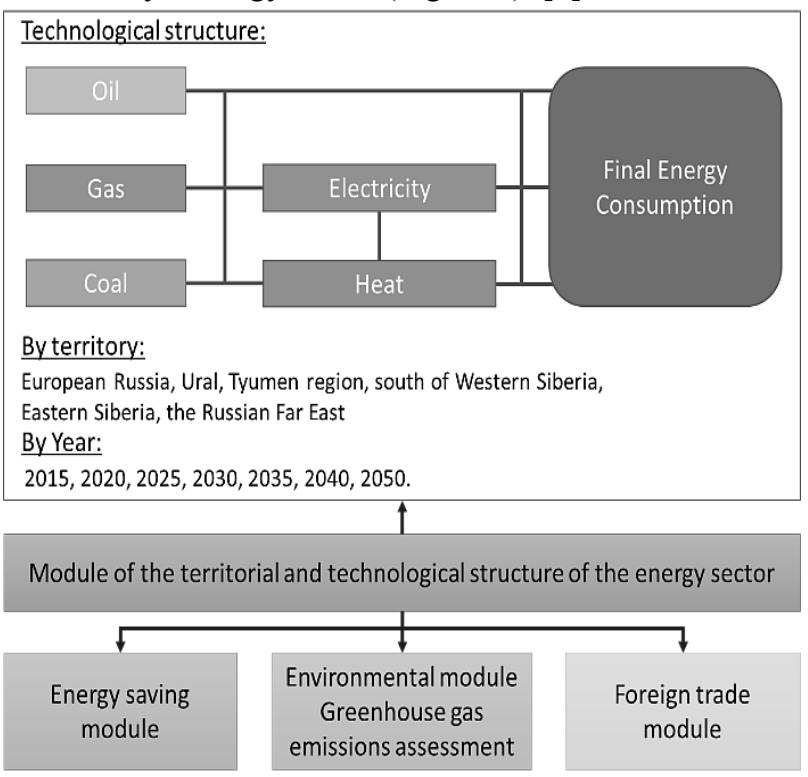

Fig. 1. Structure of the dynamic optimization model of the country's energy sector

\footnotetext{
* Corresponding author: lagerev@isem.irk.ru
} 
The model describes the process of development of the territorial and production structure of the energy sector up to 2050 in dynamics (modelled in five-year increments) as applied to large aggregated regions defined based on their geographical location.

\section{Research findings}

The model-based studies enabled us to form a wellbalanced rational structure of regional energy sector development for the country as a whole and for each of the Asian regions (Western and Eastern Siberia, the Russian Far East) and outline their role in the energy sector of the country.

Backed by the program documents $[1-4,8]$ and other materials [9-11], as well as by the authors' previous research [12-15], we are able to identify a number of trends in the development of the energy sector of the country and its Asian regions to 2035 and with a view to 2050.

Below we study two scenarios of Russia's energy sector development to 2050: the conservative scenario and the more optimistic target scenario. The aggregated macroeconomic indicators of the country's economic development and corresponding energy consumption levels are shown in Table 1. The lower boundary of the indicator change range corresponds to the conservative scenario, while the upper boundary corresponds to the target scenario.

Table 1. Projection of economic development and energy consumption in Russia

\begin{tabular}{|c|c|c|c|c|}
\hline \multirow{2}{*}{ Indicator } & \multirow{2}{*}{2015} & \multicolumn{3}{|c|}{ Projection } \\
\hline & & 2025 & 2035 & 2050 \\
\hline GDP*, bln. USD & 1.555 & $1.850-2.105$ & $2.300-2.960$ & $3.160-4.610$ \\
\hline $\begin{array}{l}\text { GDP growth rate as } \\
\text { compared to } 2015, \%\end{array}$ & 100 & $119-135$ & $148-190$ & $196-286$ \\
\hline $\begin{array}{l}\text { Average annual GDP } \\
\text { growth rate, } \%\end{array}$ & - & $1.7-3.1$ & $2.2-3.5$ & $2.1-3.0$ \\
\hline Population, mln. people & 146 & 146 & $145-146$ & $145-147$ \\
\hline $\begin{array}{l}\text { GDP per capita, thous. } \\
\text { USD per person }\end{array}$ & 10.7 & $12-14$ & $16-20$ & $22-31$ \\
\hline $\begin{array}{l}\text { Domestic primary energy } \\
\text { consumption, mln. tce }\end{array}$ & 964 & $1.073-1.091$ & $1.143-1.174$ & $1.144-1.190$ \\
\hline $\begin{array}{l}\text { Primary energy } \\
\text { consumption growth } \\
\text { rates as compared to } \\
2015, \%\end{array}$ & 100 & $111-113$ & $118-122$ & $119-123$ \\
\hline $\begin{array}{l}\text { GDP energy intensity, } \\
\text { tce per thous. USD }\end{array}$ & 0.62 & $0.56-0.53$ & $0.5-0.4$ & $0.4-0.3$ \\
\hline $\begin{array}{l}\text { Energy intensity } \\
\text { decrease rate as } \\
\text { compared to } 2015, \%\end{array}$ & 100 & $92-87$ & $79-66$ & $59-43$ \\
\hline
\end{tabular}

Average annual GDP growth rates for assumed scenarios were covered within the following ranges: $1.7-$ $3.1 \%$ for the period between 2015 and 2025 and $2.2-3.5 \%$ for the period between 2026 and 2035. It is assumed that in the years to come (2036 to 2050) the GDP growth rate will drop to $2.1 \%$ under the conservative scenario, and to $3.0 \%$ under the target scenario.

One of the prerequisites for the assumed scenarios of economic development of Russia to materialize is the growth (as compared to 2015) of domestic primary energy consumption: by $11-13 \%$ by 2025 , and by $19-23 \%$ - by 2035-2050.

To this end, the consumption of petroleum products in the period between 2015 and 2050 should increase by 15 $17 \%$ and that of natural gas - by $23-28 \%$, while the consumption of coal and other solid fuels should decrease by $5 \%$ under the conservative scenario and should increase by $1.5 \%$ under the target scenario. The consumption of non-carbon energy resources (HPPs, NPPs, non-conventional renewables) should increase by $33-43 \%$.

The resulting energy consumption structure in Russia is shown in Figure 2.

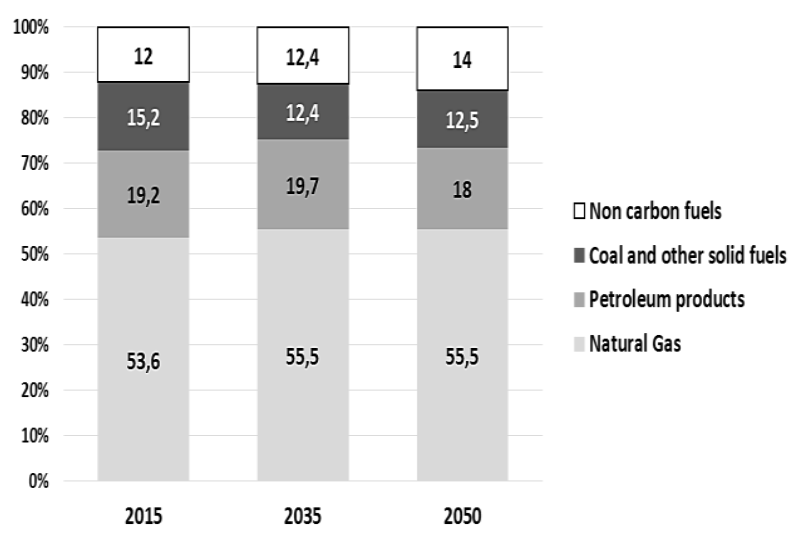

Fig. 2. Projected structure of energy consumption in Russia, \%

As shown in Figure 2, natural gas will remain the dominant resource in primary energy consumption in Russia throughout the period under review: its share in the demand structure will increase from $53.6 \%$ in 2015 to 55 $56 \%$ by 2050 .

The share of petroleum products in the structure of primary energy consumption by 2050 under the conservative scenario will decrease to $18.5 \%$ (as compared to $19.2 \%$ in 2015 ), and, under the target scenario, to $18 \%$, while the share of coal and other solid fuels will decrease from $15 \%$ to $12-12.5 \%$.

The share of non-carbon energy sources in domestic consumption will remain at about $12 \%$ until 2035 and only by 2050 will it increase to $13.5-14 \%$.

The results of the study show that after 2035 the consumption of energy resources in the Asian regions of the country will grow faster than before. Over the period under review (2015-2050) energy consumption in the Asian regions may increase by $28-35 \%$ (in the country as a whole - by 19-23\%).

At present, Russia enjoys the status of the world's largest exporter of energy resources, the sales volume of which is slightly less (by 3\%) than their domestic consumption in the country.

Within the given timeframe, export volumes and structure will be mainly determined by the factors of economic feasibility and will depend not only on fuel prices in the international energy markets but also on prices and production volumes of Russian producers.

At the same time, the political component will also play an important role. 
The dynamics of international fuel prices assumed for modelled calculations is given in Table 2, while that of domestic prices is given in Table 3 .

Table 2. Projection of fuel prices* in international markets

\begin{tabular}{|l|c|c|c|c|}
\hline \multicolumn{1}{|c|}{ Indicator } & \multirow{2}{*}{2015} & \multicolumn{3}{|c|}{ Projection } \\
\cline { 3 - 5 } & & 2025 & 2035 & 2050 \\
\hline Oil, USD per barrel & 45 & $50-65$ & $50-65$ & $65-80$ \\
Natural gas, USD per 1,000 $\mathrm{m}^{3}$ & & & & \\
Europe & 240 & $250-290$ & $250-290$ & $300-350$ \\
Countries of Northeast Asia: & & & & \\
$\quad$ China (pipeline gas) & 250 & $275-290$ & $300-345$ & $330-380$ \\
$\quad$ Japan (LNG) & 310 & $340-380$ & $380-450$ & $430-500$ \\
Steam coal, USD per ton & 63 & $65-70$ & $60-75$ & $60-80$ \\
\hline
\end{tabular}

Note: *reported in constant 2015 prices.

Source: documents of strategic development of the Russian energy sector to 2035 and authors' estimates.

Table 3. Projection of fuel prices* in Russian markets

\begin{tabular}{|l|c|c|c|c|}
\hline \multirow{2}{*}{ Indicator } & \multirow{2}{*}{2015} & \multicolumn{3}{|c|}{ Projection } \\
\cline { 3 - 5 } & & 2025 & 2035 & 2050 \\
\hline European market & & & & \\
Natural gas, USD per 1,000 $\mathrm{m}^{3}$ & $90-105$ & $120-130$ & $120-150$ & $125-185$ \\
Steam coal, USD per tce & $45-50$ & $50-60$ & $50-75$ & $65-80$ \\
\hline Asian market & & & & \\
Natural gas, USD per 1,000 $\mathrm{m}^{3}$ & $95-100$ & $120-135$ & $145-170$ & $170-200$ \\
Steam coal, USD per tce & $35-45$ & $50-60$ & $50-60$ & $55-65$ \\
\hline
\end{tabular}

Note: *reported in constant 2015 prices.

Source: documents of strategic development of the Russian energy sector to 2035 and authors' estimates.

The projected exports of Russian energy resources that we arrived at given international and domestic prices of fuel and energy supplies as assumed in calculations are shown in Table 4.

Table 4. Projection of exports of Russia's energy resources

\begin{tabular}{|l|c|c|c|c|}
\hline \multirow{2}{*}{ Indicator } & \multirow{2}{*}{2015} & \multicolumn{3}{c|}{ Projection } \\
\cline { 3 - 5 } & & 2025 & 2035 & 2050 \\
\hline Exports, total, mln. tce/\%, & $\underline{925}$ & $\frac{1,050-}{1,090}$ & $\frac{1,010-}{1,070}$ & $\underline{915-}$ \\
Inclusive of the following: & 100 & $114-118$ & $\frac{1,060}{96-98}$ & $\frac{87-97}{276-312}$ \\
Oil and petroleum products, & 406 & $377-390$ & $321-338$ & 276 \\
mln. tons & & & & \\
Natural gas, bln. m ${ }^{3}$ & 204 & $290-294$ & $308-323$ & $272-327$ \\
Coal, mln. tce & 115 & $180-194$ & $200-215$ & $200-230$ \\
Electricity (balance), & 7 & $21-22$ & $22-28$ & $62-67$ \\
billion kWh & & & & \\
\hline
\end{tabular}

It follows from the above that in 10 years (i.e., by 2025) the exports of Russian energy resources will increase by $14-18 \%$, and then decline by 2050 : under the conservative scenario - by $13 \%$, under the target scenario - by $3 \%$.

As is evidenced from Figure 3, oil exports will dominate in the structure of energy resources exports from Russia in the period under review, while its share in the structure of exports will gradually decrease: from $62 \%$ in 2015 to $45 \%$ by 2035 and to $42-43 \%$ by 2050 .

Within the given timeframe, the European export destinations will remain the dominant ones for Russia, but their share in total exports will decrease and by 2050 it will amount to $55-62 \%$ (as compared to $80 \%$ in 2015 ).

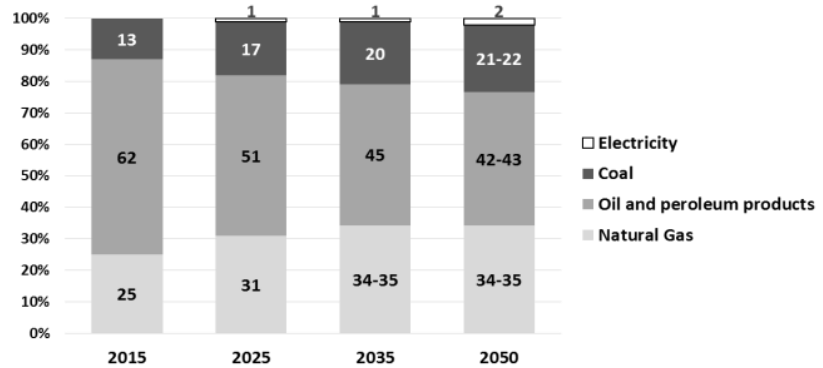

Fig. 3. Structure of Russian energy resources exports, $\%$

The decline in the share of oil exports will be substituted mainly with natural gas and coal. At the same time, the share of natural gas in the structure of exports will increase from $25 \%$ in 2015 to $34-35 \%$ by 2035 and will remain at this level until 2050.

The share of coal will grow from $13 \%$ in 2015 to 21 $22 \%$ by 2050 .

Figure 4 shows the structure of Russian energy resources exports by export destinations.

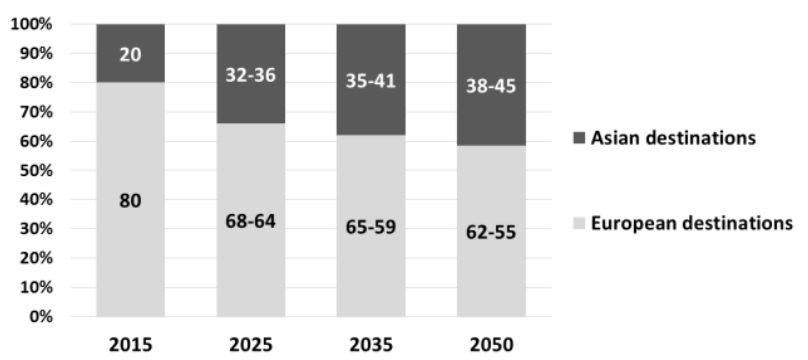

Fig. 4. Structure of Russian energy resources exports by destinations

At the same time, the availability of economically viable energy resources in the Asian regions of Russia and the growing demand for them in the NEA countries make Asian destinations of energy exports from Russia more promising. It is estimated that by 2050 the share of energy exports to Asian destinations in total energy exports may increase to $38-45 \%$ as compared to $20 \%$ in 2015 .

The volume of energy resources production in Russia resulting from our modelled calculations is shown in Table 5 .

Table 5. Energy production in Russia to 2050

\begin{tabular}{|l|c|c|c|c|}
\multicolumn{1}{|c|}{ Indicator } & $2015 *$ & \multicolumn{3}{|c|}{ Projection } \\
\cline { 3 - 5 } & & 2025 & 2035 & 2050 \\
\hline $\begin{array}{l}\text { Production, total, } \\
\text { mln tce/\%, inclusive } \\
\text { of: }\end{array}$ & $\frac{1886}{100}$ & $\frac{2.117-2.173}{112-115}$ & $\frac{2.170-2.257}{115-120}$ & $\frac{2094-2284}{111-121}$ \\
\hline $\begin{array}{l}\text { Oil and gas } \\
\text { condensate, mln. } \\
\text { tons }\end{array}$ & 534 & $526-542$ & $428-502$ & $428-466$ \\
$\begin{array}{l}\text { Natural gas, bln. } \mathrm{m}^{3} \\
\text { Coal, mln. tons }\end{array}$ & 635 & $784-799$ & $855-878$ & $832-907$ \\
$\begin{array}{l}\text { Other solid fuels, } \\
\text { mln. tce }\end{array}$ & 32 & $447-470$ & $477-510$ & $485-539$ \\
$\begin{array}{l}\text { Hydropower, TW·h } \\
\text { Nuclear power, }\end{array}$ & 170 & $207-208$ & $215-221$ & $251-260$ \\
$\begin{array}{l}\text { TW.h } \\
\text { Non-conventional } \\
\text { renewable energy, } \\
\text { TW·h }\end{array}$ & 2.4 & $9-10$ & $256-263$ & $330-361$ \\
\hline
\end{tabular}

Note: $* 2015=100 \%$ 
Our studies attest to the need to increase energy production in Russia by $11-21 \%$ by 2050 (as compared to 2015) to meet the country's projected domestic demand for energy resources and their exports.

It is estimated that oil and gas condensate production in the country will decrease by 2050 (as compared to 2015 ) by $20 \%$ under the conservative scenario and by $13 \%$ under the target scenario.

Natural gas production will increase (as compared to 2015 ) by $35-38 \%$ by 2035 and by $31-43 \%$ by 2050 .

Table 6 shows the share of the Asian regions in the projected energy resources production in Russia.

Table 6. Share of Asian regions in energy resources extraction (production) in the country, \%

\begin{tabular}{|l|c|c|c|c|}
\hline \multirow{2}{*}{ Indicator } & \multirow{2}{*}{2015} & \multicolumn{3}{|c|}{ Projection } \\
\cline { 3 - 5 } & & 2025 & 2035 & 2050 \\
\hline Energy, total, including: & 79 & 82 & 83 & 81 \\
Oil and gas condensate & 70 & 73 & $75-84$ & $78-79$ \\
Natural gas & 92,5 & $93-94$ & $94-95$ & $89-87$ \\
Coal & 94 & $96-97$ & $96-97$ & $97-98$ \\
\hline Note: $* 2015=100 \%$
\end{tabular}

According to the authors' estimates, by 2050 the Asian regions of Russia will account for $78-79 \%$ of oil production in the country $(70 \%$ in 2015$), 87-89 \%$ of gas production $(92.5 \%$ in 2015$)$, and $97-98 \%$ of coal production (94\% in 2015).

Table 7 shows the dynamics of energy resources production in the Asian regions of Russia.

Table 7. Energy resources production in the Asian regions of Russia

\begin{tabular}{|c|c|c|c|c|}
\hline \multirow{2}{*}{ Indicator } & \multirow{2}{*}{2015} & \multicolumn{3}{|c|}{ Projection } \\
\hline & & 2025 & 2035 & 2050 \\
\hline $\begin{array}{l}\text { Production, total, } \\
\text { mln tce/\%, } \\
\text { inclusive of: }\end{array}$ & $\frac{1,493}{100^{*}}$ & $\frac{1,736-1,790}{105-112}$ & $\frac{1,812-1,890}{121-127}$ & $\frac{1,708-1,848}{114-124}$ \\
\hline $\begin{array}{l}\text { Oil and gas } \\
\text { condensate, mln. } \\
\text { tons }\end{array}$ & 375 & $383-397$ & $359-377$ & $333-366$ \\
\hline Natural gas, bln. $\mathrm{m}^{3}$ & 588 & $734-748$ & $807-832$ & $741-787$ \\
\hline Coal, mln. tons & 351 & $431-454$ & $460-494$ & $473-528$ \\
\hline $\begin{array}{l}\text { Other solid fuels, } \\
\text { mln. tce }\end{array}$ & 9 & 8 & 8,6 & 9,4 \\
\hline Hydropower, TW·h & 108 & 137 & $145-148$ & $170-175$ \\
\hline $\begin{array}{l}\text { Nuclear power, } \\
\text { TW·h }\end{array}$ & 0,2 & 0,5 & 0,5 & 0,6 \\
\hline $\begin{array}{l}\text { Non-conventional } \\
\text { renewable energy, } \\
\text { TW·h }\end{array}$ & 0,8 & $2,5-3,8$ & $9-13$ & $18-20$ \\
\hline
\end{tabular}

At present, the main oil production area is Western Siberia. It is projected that oil production in Western Siberia (as compared to 2015) may decline by $25 \%$ (by 80 million tons) under the conservative scenario by 2050 , and by $17 \%$ (by 55 million tons) under the target scenario.

In the period under review, East Siberian and Russian Far Eastern fields may make a significant contribution to oil production, with production growth by 2050 to $55-60$ million tons in East Siberia and 45-48 million tons in the Russian Far East.
Western Siberia where gas production may grow by 2035 and then decline by 2050 remains the main gasproducing region within the given time frame.

Eastern Siberia and the Russian Far East will become promising gas production regions in the period under review. Given the favourable market conditions in the Asian export destinations, gas production in Eastern Siberia will increase to $50-65$ billion cubic meters by 2050 and to 72-77 billion cubic meters in the Russian Far East.

Coal production in Western Siberia is projected to grow by 2050 to $275-315$ million tons (as compared to 215 million tons in 2015).

Significant growth in coal production will be provided by Eastern Siberia and the Russian Far East. According to the authors' estimates, coal production may grow by 30 $42 \%$ by 2050 in Eastern Siberia, while increasing 1.8-1.9 times in the Russian Far East.

Production of non-carbon electric power sources in the Asian regions of the country (nuclear power, hydropower, non-conventional renewable sources) will increase by $23-$ $28 \%$ by 2035 and by $34-39 \%$ by 2050 .

That having been said, their share in the country's energy production will increase insignificantly: from $6.1 \%$ in 2015 to $6.3 \%$ by 2035 and to $7.5 \%$ by 2050 .

Figure 5 shows the projected dynamics of energy resources exports from the Asian regions of Russia.

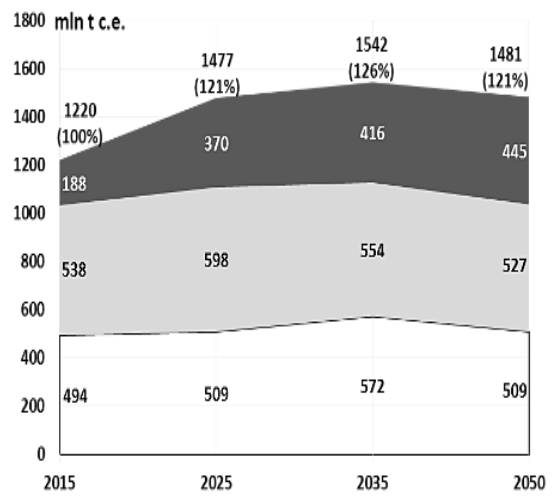

IExports (Asian destinations) - Exports (European destinations) QEuropean Russia

Fig. 5. Exports of energy resources from the Asian regions (target scenario)

In 2015, 1,220 million tce of energy resources (or $82 \%$ of their total production) were exported from the Asian regions of Russia, $41 \%$ of which were for the needs of the European part of the country and 59\% were for exports.

According to the authors' estimates, the exports of energy resources from the Asian regions will increase by $21-26 \%$ by 2035 , and then will decrease by $4-8 \%$ by 2050 .

Figure 6 shows how the percentage ratio with respect to the destinations of energy resources exports from the Asian regions of Russia may change:

- the share of energy resources exported to the European part of the country in total exports will decrease and by 2050 will amount to $37-34 \%$ (as compared to $41 \%$ in 2015).

- the share of Asian energy resources exported to European destinations will decrease from $44 \%$ in 2015 to $39-36 \%$ by 2050 .

- the share of Asian energy resources exported to Asian destinations will increase from $15 \%$ in 2015 to 24 $30 \%$ by 2050 . 


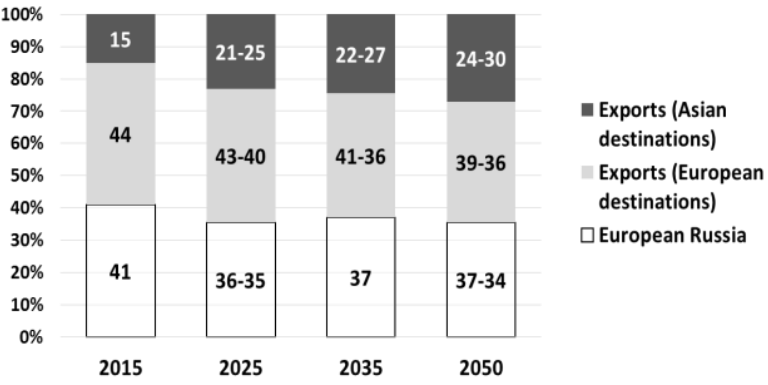

Fig. 6. Structure (by destination) of energy resources exports from the Asian regions

\section{Conclusion}

1. Under the considered scenarios of Russia's economic development, energy consumption in the country (in the period from 2015 to 2050) should increase by $19-23 \%$, with energy consumption in Asian regions increasing by $28-35 \%$. As a result, the share of Asian regions in the total energy consumption of the country will increase from $29 \%$ in 2015 to $31-32 \%$ by 2050 .

2. Within the timeframe under review the Asian regions will still remain the main suppliers of energy resources, both to the domestic market of the country and for exports.

3. According to the authors' estimates, the exports of energy resources from Asian regions may increase by 21$26 \%$ by 2035 and then decrease by $4-8 \%$ by 2050 .

At the same time, the proportion of exports of energy originating from Asia will also change in terms of their destinations:

- exports to European Russia will decrease from $41 \%$ in 2015 to $34-37 \%$ by 2050 ;

- exports to European destinations will decrease from $44 \%$ to $36-39 \%$;

- exports to Asian destinations (Northeast Asian countries) will increase from $15 \%$ to $24-30 \%$.

4. To meet domestic demand for energy resources and their exports, energy production in Russia's Asian regions should grow by $21-27 \%$ by 2035 (as compared to 2015), and then decline by $6-2 \%$ by 2050 .

By 2050, Asian regions are expected to account for $78-79 \%$ of the country's oil production $(70 \%$ in 2015$)$, $87-89 \%$ of natural gas production $(92.5 \%$ in 2015$)$, 97$98 \%$ of coal $(94 \%$ in 2015$), 67-68 \%$ of electricity produced by HPPs (64\% in 2015$)$.

The research was carried out under State Assignment 174.2 of the program for basic research of the Siberian Branch of the Russian Academy of Sciences (reg. No. AAAA-A17$117030310435-0$ ) and was supported in part by a grant by the Russian Foundation for Basic Research (project No. 18-51094006).

\section{References}

1. The energy strategy of the Russian Federation to 2035 (approved on June 9, 2020). Available at: //https://minenergo.gov.ru/node/1920

(Accessed 10.09.2020). (in Russian)

2. The program for the development of the coal industry of Russia to 2035 (approved on June 13, 2020). Available

at: http://static.government.ru/media/files/OoKX6PriWg Dz4CNNAxwIYZEE6zm6I52S.pdf (Accessed 10.07. 2020). (in Russian)

3. The general scheme (Master plan) for the installation of electric power industry facilities to 2035 (approved by order No. 1209-r of the Government of the Russian Federation on June 9, 2017). (in Russian)

4. Projection of scientific and technological development of the energy sector of Russia to 2035 . (Approved by the Minister of Energy of the Russian Federation on October 14, 2016). (in Russian)

5. The eastern vector of the energy strategy of Russia: its current state and a future outlook / ed. by N.I. Voropai, B.G. Saneev; Melentiev Energy Systems Institute. Novosibirsk: "GEO" academic publishers, 368 p. (2011) (in Russian)

6. Saneev B.G. Hierarchical modeling in the study of the energy sector development of the country and its regions // Hierarchical modeling of energy systems / ed. by N.I. Voropai, V.A. Stennikov: Melentiev Energy Systems Institute, Siberian Branch of the Russian Academy of Sciences. Novosibirsk: "GEO" academic publishers, 314 p. (P.93-108) (2020) (in Russian)

7. Lagerev A.V. Modeling the long-term development of the energy sector. Methods and models for projections of energy-economy interactions / Yu. D. Kononov, E. V. Galperova et al. Novosibirsk: Nauka, p. 102-126 (2009) (in Russian)

8. Projection of the social and economic development of the Russian Federation to 2036 / Ministry of Economic Development of the Russian Federation. Moscow, 47 p. Available at: http://economy.gov.ru/minec/about/structure/depmac ro/201828113 (Accessed 20.03.2019) (2018) (in Russian)

9. Oil and gas sector of Russia - 2018. Part 1. Gas industry - 2018: long-term trends and the current state / I.V. Filimonov, V.Yu. Nemov, I.V. Provornaya et al /ed. by A.E. Kontorovich. Novosibirsk: Trofimuk Institute of Petroleum Geology and Geophysics, SB RAS, 2019, 84 p. (in Russian)

10. Oil and gas sector of Russia - 2018. Part 2. Gas industry - 2018: long-term trends and the current state / I.V. Filimonov, V.Yu. Nemov, I.V. Provornaya et al /ed. by A.E. Kontorovich. Novosibirsk: Trofimuk Institute of Petroleum Geology and Geophysics, SB RAS, 2019, 63 p. (in Russian)

11. BP: World energy outlook to 2035. Russia on the global energy market. Available at: http://oilgascom.com/prognoz-razvitiya-mirovojenergetiki-do-2035-goda-rossiya-na-globalnomrynke (Accessed 20.02.2019). (in Russian)

12. Saneev B. Regional priorities of the Eastern energy policy of Russia // E3S Web of Conferences. Vol.77. ID: $\quad 01006 . \quad 2019.2$ DOI: 10.1051/e3sconf/20197701006 
13. Lagerev A.V., Khanaeva V.N. Development priorities of the energy sector of the Asian regions of Russia in the long term. Spatial Economics, 2017, No. 3, p. 154166. (in Russian)

14. Saneev B.G., Ivanova I.Yu., Tuguzova T.F Development of renewable energy in the East of Russia in the first half of the XXI century against the background of overall Russian trends. Energy Policy, 2016, No.3, p. 66-73. (in Russian)

15. Voropai N.I., Podkovalnikov S.V., Saneev B.G. Multistate cooperation in North-East Asia: its current status, potential projects, energy infrastructure. Energy Policy, 2014, No.2, p. 55-64. (in Russian) 